\title{
Contextualizing Colonial Strategies in Modernist Arabic Poetics: Rethinking Colonial Politics in Post WWII Arabic Poetry
}

\author{
Saddik Gohar* \\ Professor of English Literature and Criticism, UAE University \\ *Corresponding Author: Saddik Gohar, Professor of English Literature and Criticism, UAE \\ University
}

\begin{abstract}
In spite of his anti-colonial attitudes, the great Iraqi poet, Abdul WahhabAl-Bayati does not see the West as the cultural or political antagonist or the center of hegemony and colonial power. In his response to domestic predicaments and national transformations, he approaches the West as a source of potentialities to be utilized in his confrontation with local power centers particularly the ruling regimes. Attempting to reconcile eastern and Western cultures, Al-Bayati works toward a nexus of postcoloniality and modernism competing with the great masters of Western literature. Thus, in Al-Bayati's poetry, the experience of coloniality and postcoloniality is introduced in a complex manner revealing contradictory and ambivalent tendencies toward an imperial Western center. As an epitome of the hybridity of a literature produced under Western impact, during the decades of decolonization, Al-Bayati's poetry reflects a distinguished level of conceptual and epistemological knowledge. In this context, this paper investigates the incorporation of Western modernism in postcolonial Arabic poetry in order to explore issues of great significance integral the poetic movement in contemporary Arabic literature.
\end{abstract}

\section{INTRODUCTION}

Undermining the narrow critical approaches which neglect the potential intersection between modernism and post-colonialism, this paper, in other words, explores the attempt of post-colonial Arab writers, led by the Iraqi poet Abdul-Wahhab Al-Bayati , to engage Western modernist heritage in order to articulate domestic narratives integral to the geopolitics of the Arab region in the postcolonial era . Throughout textual apprenticeship, assimilated from Western literature and culture, they combine modernism and post-colonialism into a nexus incorporating Western techniques while emphasizing variants and displacements between their nationalist perspective and that of their Western forebears. Convinced of the role played by the West in the shaping of modern Arabic cultural traditions, Al-Bayati reconstructs colonial modernism as a narrative of liberation transforming Western modernist strategies into a revolutionary construct to confront internal oppression and external hegemony. Through trans-cultural entanglements and textual appropriations of Western narratives, Al-Bayati provides diversity and insight into postcolonial Arabic poetry intensifying the awareness of other traditions and reconstructing his own heritage.

Investigating the banning of Salman Rushdie's controversial novel, Satanic Verses, in some Islamic countries, it is argued that "for the Islamic postcolonial world, the moral is clear and succinct: to write in the language of the colonizer is to write from within death itself. Postcolonial writers who write in the language of the Empire are marked off as traitors to the cause of a reconstructive post-colonialism. Postcolonial writers compose under the shadow of death" (Williams \& Chrisman 1993:277).Apparently, the consequences triggered by the publication of Rushdie's novel, in the preceding century, raised many significant questions about the relationship between East and West, colonized and colonizer. Nevertheless, the hostility toward the book, in some Middle Eastern and Islamic countries, is not related to the issue of language or what is called "the language of the empire". The use of colonial languages rarely represents a threat to Islamic culture because unlike the literature of ex-colonies in Asia, Africa, South America, the West Indies and the Caribbean, dominantly written in the language of the Western colonizers, literature in a large part of the Arab-Islamic world is composed in indigenous languages. Therefore, it is important to point out that the issue of language, 
raised above, is irrelevant because the campaign against Satanic Verses is rooted in radical constructs and religious hegemony integral to contemporary political Islamic doctrines.

Further, it is noteworthy to argue that western/colonial literatures are approached by Arab writers not as hostile texts but rather as part of the human cultural heritage liable for literary exploitation. Unlike post-colonial writers who pass through a ritual of self-brutalization in their struggle to exorcise their colonial past and destroy an old order of which they were part, Arab poets from formerly colonized countries, have actively functionalized Western traditions and forms to articulate indigenous discourses. In the post WW II era, poets from different Arab countries, engaged Western traditions transforming them into discursive dynamics to explore socio-political issues of great ramifications on the national and regional levels. Appropriating Western narratives to be used in a different language and within a different cultural context, Arab poets aim to provide more depth and insight into a fossilized tradition which fails to confront regional transformations and international challenges.

Throughout their encounters with Western culture, postcolonial Arab poets adapt non-native forms to revolutionize local perspectives deploying narratives of confrontations and challenging the ruling regimes which they found repressive and brutal. In the era of de-colonization, Arab poets led by Abdul-Wahhab Al-Bayati ${ }^{1}$ were engaged in a positive interaction with Western literature to overcome alienation and disappointment integral to their cultural crisis. Entangled in the labyrinth of regional political events, particularly the Palestinian tragedy in 1948 and the rise of the nation-state in the region, the new generation of Arab poets was seeking salvation in the West and its cultural paradigms. Though literature written in indigenous languages is often concerned with the construction of national and cultural identities, the situation in the Arab world in the post WWII era pushed postcolonial Arab poets toward the West in an attempt to develop a poetics of hybridity able to confront the new challenges emerging in the region.

The global concerns of postcolonial Arab poets who came under the impact of Western modernism indicate the gradual disappearance of models of literary history that isolate poets by race, language, gender or geography. Nevertheless, the entanglement between the Arab poets and the West in the post WWII era raises the controversial issue of the relationship between post-colonialism and modernism as reflection of the complex interaction in the works of transnational figures particularly the Iraqi poet Abdul-Wahhab Al-Bayati. Drawing an analogy between third world literature and post-colonialism, AijazAhmed points out:

Postcoloniality is postmodernism's wedge to colonize literatures outside Europe and its North American offshoots - which I take the liberty to understand as saying that what used to be known as 'Third World Literature' gets re-christened as 'postcolonial literature' when the governing theoretical framework shifts from third world nationalism to postmodernism (Ahmed 1997: 276).

Moreover, AijazAhmed argues that during colonization "the ruling class of a colony is located outside the colony and the colonial state is the instrument of that externally-based ruling class" (Ahmed 1992: 204). In a related context, ArifDirlik points out that the term "postcolonial" refers to conditions in formally colonized countries after the period of colonialism. Nevertheless, postcoloniality has been released from "the fixity of third world location" and consequently, "the identity of the postcolonial is no longer structural but discursive" (Dirlik 1997: 297). Therefore, the term "postcolonial", according to Dirlik, represents an attempt to "regroup intellectuals of uncertain location under the banner of post-colonialism" (297). With the emergence of de-colonization "this structural feature of the dominated formation no longer applies and the formation therefore ceases to be colonial, regardless of any other kind of dependence" (Ahmed 1992: 204).

On this basis, AijazAhmed illustrates that the line of demarcation between the so-called "colonial" and "postcolonial" categories, disappears completely and both terms, according to him have no

\footnotetext{
${ }^{1}$ The Iraqi poet, Abdul-Wahhab Al-Bayatiwas born in Baghdadin 1926. In 1950, he graduated from Baghdad's Teachers College with a BA in Arabic language and literature. He worked as a teacher from 1950 to 1953 until he was expelled from his job and his country due to his ideological commitments. As a political refugee, AlBayati lived in many countries in the Arab world and Europe and most of his works were published outside Iraq. Due to his political views, Al-Bayatiwas deprived twice from his Iraqi nationality, once during the 1960's and once during Saddam Hussain's regime.
} 
analytic value nor any theoretical status, when they are mobilized to homogenize very complex structures of intellectual productions or the trajectories and subjectivities of individual writers and critics or broad intellectual strata. For particular intellectual or clusters of them, colonial cultural ambience can last far beyond the moment of de-colonization (Ahmed 1992: 205). Further, Ahmed points out that "colonialism" is used as a term or category associated with the "periodisation of history as regards the rule over the people of a particular country by ruling classes of another country" (Ahmed 1992: 204).

Ironically, in the Arab world and due to geopolitical reasons, there was no wide difference between the colonial era and the age of de-colonization because the legacies of the ex-colonizers were inherited by tyrannical regimes dominating the fate of the Arab people and dragging the Arab homeland backward toward the Stone Age. In the Arab world, political and literary discourses were in a state of harmony during the colonial era when political leaders and poets speak the same language of resistance and struggle against Western imperialism. In the era of decolonization, the state apparatuses, in the Arab world, were dominated by military and tribal leaders who brutalized their people; therefore, they came into confrontation with the poets and the intellectual elite. The conflict between the Arab poets and the privileged groups that dominate the ruling regimes reached a juncture in the aftermath of the Palestinian tragedy in 1948. The defeat of the Arab armies in the 1948 war against Israel and the rise of dictatorial nation-states forced the young generation of Arab poets to come into confrontations with the totalizing, monolithic official policies of the regimes. In their endorsement of a pluralistic, multivalent and anti-hegemonic counter-narratives, postcolonial Arab poets went toward the West incorporating Western traditions into Arabic literature.

Nevertheless, the integration of Western forms and literary techniques into postcolonial Arabic poetry is not a feature of the colonial legacy or manifestation of cultural dependency. Instead, Arab poets, in the post WWII era utilized Western forms and strategies in an innovative way transforming them into a dynamic of protest and revolution against local, hegemonic policies. Finding solace in Western literature particularly the modernist project of T.S. Eliot, postcolonial Arab poets such as AbdulWahhab Al-Bayati, Badr Shaker Al-Sayyab ${ }^{2}$ and others appropriate modernist poetic traditions and Western narratives transforming them into a poetic dynamics to articulate domestic issues integral to the Arab world in the era of de-colonization.

A scrutinized analysis of postcolonial Arabic poetry reveals the limitations of narrow critical approaches which ignore the potential intersection of Western modernism and post-colonialism. Associating modernism with postmodernism and colonialism with post-colonialism, critics neglected the complex relationship between modernism and post-colonialism ignoring how postcolonial poets like Al-Bayati and Al-Sayyab transform modernist texts to articulate new experiences. Unlike poets who express doubts toward Western traditions, Al-Bayati and Al-Sayyab utilize Western modernism to express the complexities of the Arab experience in the era of decolonization. Appropriating Western narratives to serve local purposes, they blend modernism with post-colonialism providing their people with a communal voice, a revolutionary anthem.

Regardless of the entanglements between modernism and post-colonialism, many critics deny the existence of any bond between the two movements dealing with modernism as an evil to be overcome. Equating modernism with colonialism and postmodernism with post-colonialism, Stephen Slemon, for instance, points out that colonialism is the "armed version" of modernism emphasizing that "postmodernism and post-colonialism have emerged in reaction to this single cultural event [modernism] (Slemon 1989: 8). Apart from his criticism of post-modernism for its assimilation of many cultural and imperialistic features of modernism, Slemon concludes that postmodernism and post-colonialism have participated in "decolonizing Western culture" from "a residual modernism" (Slemon 1989: 15). Kwame Anthony Appiah, like Slemon, denounces modernism demonstrating that postmodernism and post-colonialism emphasize a contingent humanism but expressing a

\footnotetext{
${ }^{2}$ See my article "Toward a Dialogue between the Arab World and the West: The City Analogy in the Poetry of T.S. Eliot and Badr Shaker Al-Sayyab". Journal of Middle Eastern and North AfricanIntellectual and Cultural Studies. Vol. 4 (2006): 43-67.
} 
common "concern for human suffering while still rejecting the master narratives of modernism" (cited in Gohar 2000: 28). ${ }^{3}$

Likewise, Linda Hutcheon denies any common aspects between modernism and post-colonialism pointing out that postmodernist and postcolonial writers attempt to "negotiate their relationship to the past because of the ahistorism of colonial modernism" (cited in Gohar 2000: 19). ${ }^{4}$ Ignoring the relationship between modernism and post-colonialism, Simon During defines the basic aims of postcolonialism in anti-modernist terms: "to achieve an identity uncontaminated by universalistic or Eurocentric concepts or images" (During 1995: 125). Besides, George Gugelburger distinguishes between post-colonialism and modernism in terms of the differences between what he calls the bilingual language of "third world literature" and the "polyglot aspects of the Euro-American modernist tradition" (Gugelburger 1991:501). Interpreting modernism as "an international movement, elitist, imperialist, totalizing willing to appropriate the local while being condescending toward its practice", Frank Davey denies any connection between modernism and post-colonialism (Davey 1998: 119).

Claiming that the "post" in post-colonialism means "against", critics widen the gap between postcolonialism and other literary movements particularly modernism. Therefore, attempts by postcolonial poets to utilize modernist traditions in a post-colonial context are unfortunately underestimated. Nevertheless, critics who study African American and Caribbean literatures open new horizons in the relationship between modernism and post-colonialism by engaging modernist strategies which seem to be different from the traditional European model. For example, Houston Baker, in his study of the Harlem Renaissance, argues that African American poets, in the 1920's, incorporated complementary strategies to shape liberating modernist poetics. Nevertheless, he defines these new modernisms in binary opposition to Western modernism. Consequently, Baker points out that African and African American modernism is "radically opposed" to Western history therefore it has little to do with the "Joycean or Eliotic projects" (Baker 1987: 15). Similarly, Simon Gikandi, in his study of Caribbean literature, demonstrates that Caribbean modernism is "opposed to European notions of modernism" particularly "the high modernist aesthetic" of Pound, Eliot and Joyce (Gikandi 1992: 9).

Unlike Caribbean writers who attempt to undermine the foundations of European model of progress and temporal closure represented by the Pound-Eliot modernist project, Arab poets, in the post WWII era, incorporate Western modernist strategies to serve local contexts. Rejecting to remain hostages to the historical ghetto, the postcolonial traumatic experience, prominent Arab poets engage a Western colonial tradition which attracted them culturally and appalled them politically. In other words, the interest in Western literature stimulates Arab poets to partake in dialogues with Western masters particularly T.S. Eliot. In spite of his endorsement of the British colonial project, Eliot's literary works have gained popularity in "the former colonial territories once controlled by Britain" particularly in the Arab world (De Young 2000: 3).

In spite of his attitude toward colonization, Eliot's literary heritage was received positively by postcolonial Arab writers who were attracted to his modernist theories. Regardless of his criticism of various interest groups, like the missionary organizations, which participated in the colonial project, Eliot argues that colonial domination was beneficial to the colonized countries. In Christianity and Culture, he does not acknowledge the damages done to native culture during the colonial era: to point to the damage that has been done to the native cultures in the process of imperial expansion is by no means an indictment of empire itself, as the advocates of imperial dissolution are only too apt to infer (Eliot 1948: 167).

Due to a variety of reasons, Eliot's literary works and critical theories found response from postcolonial Arab poets regardless of his interest in the colonial project. In his discussion of the literary scene in the Arab world, in the aftermath of WWII, Muhsin Al-Musawi speaks about an emerging attitude dominating Arabic poetry which paves the way for Eliot's impact on Arab poets.

${ }^{3}$ For more details, see Kwame Anthony Appiah's article, "Cosmopolitan Patriots". Critical Enquiry23 (1997): 617-639.

${ }^{4}$ For a critical investigation of Hutcheon's views on the topic see her article "Circling the Downspout of Empire: Post-colonialism and Postmodernism". Ariel 20/4 (1989): 7-16. 
Due to this revolutionary attitude, Arab poets, according to Al-Musawi, attempt to construct a new poetics, in tandem with or in separation from classical poetics, with special emphasis on theories of persona, mask, and dramatic monologue, along with images, symbols, fertility, myths and historical constructs. There was no separation then between this epistemological stance and their engagement in the struggle against exploitation inside and the fight against the threat from outside. Intellectuals felt the need for an avant-garde to lead the mass population (Al-Musawi 2002: 173).

Under the impact of Eliot, postcolonial Arab poets developed new poetic dynamics to articulate the ambitions and frustrations of a nation battered by recurrent defeats and plagued with repressive regimes. Recognizing the limitations of a local poetic tradition that failed to confront the challenges of the post WWII era, they advocate Western poetic forms and innovative techniques to explore national issues and confront domestic hegemony. Under the impact of Eliot's literary traditions, poets such as Al-Bayati, Al-Sayyab and others were able to utilize Western modernist forms like the prelude, the interior monologue and the mythic method providing more insight and flexibility into the Arabic poetic tradition.

Discussing the influence of Western literature on modern Arab writers, M.M. Badawi points out that "the most significant authors in modern Arabic literature have almost without exception, been directly or indirectly exposed to Western cultural influence" (Badawi 1975: 2). Badawi argues that the great interest of Arab poets and critics in Eliot's literary heritage after WWII made Eliot appear in Arabic literary canons as synonym for modern English poetry. Coming under the impact of Eliot's literary heritage, particularly his concept of tradition, Al-Bayati points out thattradition should not be approached merely as an assemblage of human knowledge and experience (Al-Bayati 1981: 19) ${ }^{5}$. To him, tradition not only represents the past but also includes the continuous ritual of appropriation and assessment in which the poet re-evaluates and reconstructs the past while articulating the present and the future through sophisticated art.

Al-Bayati's concept of tradition is explicitly an echo of Eliot's theory on tradition. Eliot points out that no artist makes a complete meaning alone and the appreciation of a poet or the significance of his works results from placing him within tradition. In other words, a poet should be compared and contrasted with the dead masters in order to see his contribution to tradition. In "Tradition and Individual Talent", Eliot argues that modern poets should be aware of tradition and should contribute to it. He also points out that real artists belong to a community and are dedicated to tradition. Being convinced that no artist is able to make a contribution alone because "the most individual parts of work may be those in which the dead poets, his ancestors assert their immortality most vigorously" (Lodge 1972: 71), Eliot emphasizes the importance of assimilating tradition into contemporary works. To Eliot, a poet can be evaluated only in connection with his involvement in tradition and through his relationship with his forebears: "his appreciation is the appreciation of his relation to the dead poets and artists" (Lodge 1972: 72).

In "Tradition and Individual Talent", Eliot argues that poetry is not reflection of emotions because it is not conceived in the personal / subjective romantic context. To Eliot, "poetry is not a turning loose of emotions but an escape from emotion, it is not the expression of personality but an escape from personality" (Lodge 1972: 76). Eliot also emphasizes the significance of engaging tradition in contemporary poetic texts in order to link the present and the past. Utilizing the life history of the great Arab poet, Abu Al-Ala'a Al-Ma'ari to articulate the exile motif, Al-Bayati attempts to implement Eliot's theories of impersonality and tradition. Therefore, Al-Bayati , in "An Appointment in AlMa'ara", abandons poetic subjectivity and evokes domestic traditions identifying himself with the great Arab poet, Al-Ma'ari, because both of them are rebels who challenge the political establishment in their societies: "our poetry is not used for hypocrisy or prostitution/ we are not slaves of the Sultans any more" (Diwan Al-Bayati 1972: 366) ${ }^{6}$.

As an advocate of revolution against injustice in a postcolonial Arab world, Al-Bayati addresses his master, Al-Ma'ari, saying, "Do not you see, millions of the poor / fighting in the dark / waiting for the

\footnotetext{
${ }^{5}$ All translations from Arabic critical sources are done by the author of the book.

${ }^{6}$ All Translations from Diwan Al-Bayati/The Complete Poetic Works are done by the author of the book unless names of other translators appear in the text or the works cited.
} 
sunrise (Diwan 1972: 367). Further, in "The Plight of Abu Al-Ala'a", Al-Bayati recalls the painful experience of Al-Ma'ari, who lost his eyesight and was forced to live as a hermit for the rest of his life. Associating the miserable life of Al-Ma'ari and his people in ancient Baghdad with Hemingway's depiction of a civil war Spain, in his novel for Whom the Bell Tolls, the poet recalls the history of modern Iraq, a country devastated by internal conflicts and threatened by external interventions: "For whom the bell tolls / where can people find refuge and sanctuary? / the poor people are crucified in the marketplace / it is time for the frogs of the Sultan to be silent" (Diwan 1972: 174).

In addition to Eliot's theory of tradition, Al-Bayati incorporates Western forms particularly the mask technique to enhance poetic objectivity creating a distance between the poet and the text. Wearing the mask of Abu Al-Ala'a Al-Ma'ari, the poet-rebel, known in the Arabic literary canon as "the hostage of the two cloisters" due to his blindness and self-imposed exile, Al-Bayati explores the theme of exile in a sophisticated way. Associating himself with his master, Al-Ma'ari who longs for death as deliverance and release from life, Al-Bayati describes life in Iraq as a prison and inferno. However, the poet who was dismissed out of his country, due to political reasons, did not find solace in the "kingdom of exile" because "the heart of the world is made of stone" (Al-Bayati 1990: 207)7. Integrating Eliot's modernist theories in the Arabic literary canon, Al-Bayati reconstructs his own traditions and cultural heritage incorporating Islamic narratives in a sophisticated manner to achieve domestic purposes. Drawing upon Eliot's critical theories, Al-Bayati states that any attempt to incorporate tradition provides new perspective and opens wide horizons linking the present with the past. Thus, he engages Eliot's concept of tradition as a modernizing factor integral to the creation of a sophisticated Arabic poetics at a crucial stage in modern Arab history.

Through contact with Western literature and culture, Al-Bayati, like other postcolonial Arab poets, became aware of new traditions and myths which were subsequently transplanted into his local poetic heritage. In this context, the intersection between Western modernism and the interests of the postcolonial Arab poet played a vital role in reinforcing an inter-civilizational dialogue between the Arab world and the West opening new horizons for cultural interaction and literary hybridization. Entangled with the painful realities of a post WWII era, the postcolonial Arab poet searched for a new poetics to express his predicament. As a result of Western influence and modernist theories, Al-Bayati rediscovered his own cultural heritage turning to the myths of the ancient near East incorporating them for the first time in Arabic poetry. Attempting to revive the collapsing spirit of the Arab nation in an era of cultural deterioration and political drawbacks, he engages eastern and Western myths of fertility and resurrection blending medieval culture with ancient Egyptian, pre-Islamic, Assyrian and Babylonian traditions. The poet also incorporates Biblical and Islamic figures in addition to Arabic folklore heroes particularly Sinbad of Arabian Nights who is used as a symbol of the Palestinian refugees and the Iraqi exiles wandering in Diaspora "beggars at the doors of Arab countries".

As a result of Western influence, the postcolonial Arab poet is no longer the speaking voice of the tribe but he becomes part of the international challenges and the regional transformations which changed the geopolitical map of the Middle East:

The human conditions present itself to him in much frustration, alienation, bewilderment and rejection. The growing urbanization and industrialization of his under-developed society with their concomitant depersonalization of human relations reinforce his feeling of loss. The conflict between old values of stability and new values of mobility is rife within him. Preferring usually, the new, he pays the price in spiritual anguish. Having chosen to be a rebel, he is ready to be a martyr (Boullata 1976: xii).

There is no doubt that part of the spirit of rebellion, integral to postcolonial Arabic poetry, is related to the Arab poet's interest in the culture and literature of the colonial West. His movement toward the West is accelerated by the post WWII events particularly the tragedy of the Palestinian refugees and the rise of dictatorial regimes in the region. In other words, the post WWII era in the Arab world was an eventful period which witnessed significant changes such as the tragic consequences of the 1948 war and the emergence of military regimes in the region. The political and military developments were simultaneously paralleled by cultural and literary upheavals reaching culmination in an Arab

${ }^{7}$ See Al-Bayati'sNosusSharkiyya / Oriental Texts, Damascus, 1990. 
Poetic Renaissance whose advocates engage Western literature and culture in order to overcome local crises. Identifying the Arab world as a moral wasteland, postcolonial Arab poets draw on Western traditions and myths in order to revive a stagnant and debilitated culture giving priority to the dynamic process of reform which requires the dismantling of an old order.

\section{The Arab Wasteland And Al-Bayati's Poetry}

After the Second World War and in the aftermath of the Palestinian tragedy (1948), the image of the wasteland, assimilated from Eliot's poetry which was translated into Arabic in 1947, embodies the state of collapse and desolation integral to the Arab world. Moreover, the dictatorial regimes emerging in the regionin the era of postcolonialism, plunged the Arab world in useless conflicts and unnecessary wars which led to more deterioration and defeats. In this context, Al-Bayati attempts to restore an identity, distorted by nationalistic chauvinism blending the modernist Western legacy with the neglected myths of an Arab past. Due to Western influence, Al-Bayati seeks a new poetics incorporating historical narratives and revolutionary figures who challenge the establishment such as the warrior Arab poet, Antara (525-615 AD), the Achilles of the Arabian history, Al-Mutanabbi (915965 AD), the poet-philosopher and Al-Ma'ari, the Muslim heretic who lived in the eleventh century. Furthermore, Al-Bayati incorporated the holy figures of Ali Ibn Abi Talib, the fourth Muslim Caliph and his son Al-Hussain ${ }^{8}$ who were brutally assassinated in the early Islamic era due to tribal differences and power conflicts.

Al-Bayati is also captivated by global figures such as Lorca, Guevara, Allende, Lenin, Naser and the Algerian warriors fighting the French occupation forces. Nevertheless, Christ is the most famous figure who is predominantly used in Al-Bayati's poetry to suggest a spectrum of symbols and allusions. In Al-Bayati's poetry, Christ is utilized to fulfill political and nationalistic objectives by being associated with the revolutionary forces in Iraq, the Palestinian refugees and the Algerian rebels. Identifying his own journey in Diaspora, searching for salvation for the Iraqi people, with the crucifixion of Christ, Al-Bayati becomes the voice of all the Iraqi people who carry the burden of the cross as they are tortured in internal prisons or chased by the agents of the regime in external exiles:

I suffered from the death of the soul

In the barren land where sterile thunder

Is roaring in the mountains

Where the wind is starving

And Christ is crucified (Diwan 1972:364)

Associating Eliot's wasteland with a post WWII Iraq, Al-Bayati replicates Eliot's poetic discourse to achieve local purposes. In "What the Thunder Said ", Eliot refers to a world where "there is not even silence in the mountains/But dry sterile thunder without rain" and where people are not able to "stop and drink" because "sweat is dry and feet are in the sand" (Eliot 1984: 243). The influence of Eliot's The Waste Land is unmistakable as indicated in Al-Bayati's references to "the barren land", "the sterile thunder" and the starving wind. Further, an inter-textual reading of Al-Bayati's poetry reveals the tremendous influence of Eliot on the revolutionary Iraqi poet:

The Mufti of Cordoba is smeared with blood

$\mathrm{O}$ rivers Euphrates stop running

Until I end my song

The revolution is above all evils

It passes through death

It is a cry over the wall of sound

${ }^{8}$ Due to the impact of Western modernism on contemporary Arabic literature, Arab poets reconstruct Al-Hussain as a Christ figure to connote complex patterns of symbolism rooted in religious and geopolitical Arabic contexts. For more details, see my paper "The Use of T.S. Eliot's Literary Traditions in Contemporary Arabic Poetry", in Chewing the West: Occidental Narratives, ed. Doris Jedamski, New York: Rodopi, 2009. 
It is a sin that should be baptized (Diwan 1972: 36).

The use of river imagery, in the preceding extract, is an echo of Eliot's line: "sweet Thames run softly till I end my song" (Eliot 1984: 239) and the references to Christ in addition to narratives of baptism and crucifixion "the Mufti of Cordoba is smeared with blood" reflect Eliot's impact on the Iraqi poet. In "Death in Exile", Al-Bayati recalls Eliot's lines in "The Love Song of J. Alfred Prufrock": "I am not prince Hamlet, nor was meant to be" (Eliot 1984: 231). Wearing the mask of Hamlet, the poet attempts to capture the life of the Iraqi refugees in exile: "I am Hamlet/do not interrupt me/do not laugh at me/if I played an evil role/our world is a theater/do not switch the lights off/do not touch me, evil people/my blood smears the walls/my dagger dives into my heart/I am Hamlet without a mask/crossing the river on the wing of the tide" (Diwan 1972: 626).

In "Death in Love", Al-Bayati also wears the mask of Hamlet to articulate his poetics of exile: "I am prince Hamlet / the orphan / the prince of Denmark / I return from the kingdom of the dead / to enter the tavern / A sad clown fighting the dwarfs / in the cities of noise and trade" (Diwan 1972: 339). Associating the cities of Diaspora with Eliot's "kingdom of the dead" mentioned in "the Hollow Men", Al-Bayati describes the exile experience of the Iraqi refugees as a kind of hell. The Iraqi refugee, in Al-Bayati's poetry, is also configured through the image of Oedipus, the blind king, in the tragedy of Sophocles who personifies human misery and blindness: "the blind king was wandering in the deserts of Western exile / looking for the fire of God" (Diwan 1972: 130). In several poems, AlBayati emphasizes the theme of exile, integral to postcolonial Arabic poetry, reflecting the agony of the Iraqi people: "why are we in exile / In silence, we die / we walk on thorns and fire / unable to weep/why are we left without a homeland / dying in exile" (Diwan 1972: 635).

In the cities of exile, Al-Bayati's male refugee persona suffers from spiritual bankruptcy and sexual impotence unable to have normal relations with women. Like Eliot's emasculated persona in The Waste Land, Al-Bayati's speaker, deprived of his manhood and potency, appeals to his girlfriend to leave him alone "go back home and leave me on the cross" (Diwan 1972: 561). The poet argues that due to the pains of living in Diaspora, the Iraqi refugee is transformed into: "a man made of ice/all my emotions are left behind/in the sun city/where the curtains of the night/never fall on its walls". In his European exile, Al-Bayati, like other refugees, is torn apart by feelings of nostalgia and homesickness identifying exile with crucifixion: "we from exile to exile and door to door/wither like the lily in the dust/beggars we, O moon, we die/our train missed for all eternity" (Khouri and Algar 1975 : 111). In addition to his incorporation of Christian narratives, Al-Bayati uses other Western traditions and myths to articulate the exile motif. For example, he uses Sisyphus, as a symbol representing the agony of the Iraqi nationalists who were forced to live in exile due to their opposition to the Iraqi regime in the post WWII era: "In vain the dead attempt to escape / from the pawns of the relentless beast / in the darkness of the distant exile / the slaves roll the rock upward toward the valley / Sisyphus is reborn in the image of the displaced exile" (Diwan 1972: 193).

Utilizing Western narratives and Christian symbols, Al-Bayati describes the dilemma of the Iraqi people, trapped in exile, "like the frogs of the river" (Diwan 1972: 418) because "the roads to Iraq are dominated by herds of wolves". Describing the deplorable condition of his people, Al-Bayati, in "the Book of Poverty and Revolution", points out: "Is this silent stone from my tomb? / Is this time, crucified in the public square, from my life? / is this you O my poverty / with no face, no homeland" (Khouri and Algar 1975: 113). Al-Bayati points out that in a world dominated by tyrannical regimes, he lives "without a homeland and a shroud" (113), however,in his Western exile, the poet, regardless of his suffering as an outcast, feels that he is "a bird without a cage" (191). Addressing his homeland, the exiled poet expresses his feelings of disappointment and agony: "from the depths, I call out to you / with my tongue dried up and / my butterflies scorched over your mouth / are this snow from the coldness of your nights? (Khouri and Algar 1975: 111). From his exile, the Iraqi poet expresses his disappointed feelings toward his homeland utilizing crucifixion motifs:

Is this time crucified in the public square from my life

Is this you, $\mathrm{O}$ my time

Your face scratched in the mirror

Your consciousness dead under the feet of whores? 
And your poor people have sold you

To the dead among the living (Khouri and Algar1975: 113).

Unlike poets who attribute the catastrophes afflicting their countries in the era of the nation state to colonial politics, Al-Bayati castigates the Arab regimes for their failure to achieve the aspirations of their people. The ultimate objective of Al-Bayati's poetry is to force a radical re-thinking and reformation of forms of knowledge authorized by a fossilized cultural tradition and endorsed by tyrannical rulers who drag the Arab world backward toward the ages of darkness. Describing the socio-political situation in the Arab world in the era of de-colonization, he says:

We have been surrounded,

Since two thousand years,

By historical illusions and a language

Transformed into a prostitute

Sinking into misery in every country

From the Arabian Gulf to the Pacific Ocean (Diwan 1972: 314).

In "The Miracle", Al-Bayati criticizes the stagnant traditions of Arab culture denouncing what he calls "the hateful swamps of the East" which have no remedy. According to him, the contemporary political situation in the Arab world, in the era of de-colonization leads to complications and conflicts which could not be easily settled: "the miracles of the saints" are not able to solve the problems of the East /even the howling of the witches in the altar/ after the storm /even prayers / failed to settle the chronic problems of the East (Diwan 1972: 453).

Contrary to poets who seek to disrupt Western master narratives blaming the West for the backwardness of an ex-colonized world, Al-Bayati incorporates Euro-centric traditions, produced by Western civilization and culture to achieve local purposes. The poetry formed in this process of integration of discourses of domination occupies space that is neither Eastern nor Western. In other words, Al-Bayati's poetry is located in what HomiBhabha calls an "in-between hybrid position of practice and negotiation" (cited in Gohar 2000: 63). Further, he rejects simplified narratives of the postcolonial conditions advocated by conservative historians who see the colonial West as the reason of the deterioration of ex-colonized countries. Unlike radical Arab poets who reverse Orientalist discourse attributing agency and history to the nation-state, Al-Bayati denounces the tyrannical regimes instituted by the nation-state seeking alternatives in Western thought. This does not mean that the West and its legacies remained unquestioned in Al-Bayati's canon. While recognizing the trauma of colonization, Al-Bayati blends together the multiple legacies of the colonizer and the colonized, in the Arab world, in order to claim the rich diversity of the region's cultural and religious sources.

\section{REFERENCES}

[1] AhmedAijaz . "The Politics of Literary Postcoloniality", in Contemporary Postcolonial Theory, ed. PadminiMongia. London: Reader. pp. 276-293, 1997.

[2] In Theory: Classes, Nations, Literatures. London: Verso, 1992.

[3] Al-Bayati, Abdul Wahhab. Diwan Al-Bayati / Complete Poetic Works. Beirut: Dar Al-Awda, 1972.

[4] NosusSharkiyya / Oriental Texts. Damascus: Al-Mada , 1990.

[5] “The Contemporary Arab Poet and Tradition”. Fusul 1/4 (1981): 19-22.

[6] Al-Musawi, MuhsinJassim. "Engaging Tradition in Modern Arabic Poetics". Journal of Arabic Literature XXX III (2002): 172-210.

[7] Badawi, M.M. A Critical Introduction to Modern Arabic Poetry. New York: Cambridge University Press, 1975.

[8] Baker Houston A. Modernism and the Harlem Renaissance. Chicago: University of Chicago Press, 1987.

[9] Davey, Frank. Reading Canadian Reading. Winnipeg: Turnstone, 1998.

[10] DeYoung, Terri. T.S. "Eliot and Modern Arabic Literature". The Yearbook ofComparative and General Literature (2000): 3-21 
[11] Dirlik, Arif. "The Postcolonial Aura: Third World Criticism in the Age of Global Capitalism", in Contemporary Post-Colonial Theory, ed. PadminiMongia. London: Reader. pp. 294-319, 1997.

[12] During, Simon. "Postmodernism or Post-Colonialism Today",in The Post-Colonial Studies Reader, ed. Bill Aschroft, Gareth Griffiths and Helen Tiffin. New York: Routledge. pp. 125-192, 1995.

[13] Eliot, T.S. Christianity and Culture. New York: Harcourt Brace and Company, 1948.

[14] "The Waste Land", in The Oxford Book of Twentieth-Century English Verse, ed. Philip Larkin. New York: Oxford University Press. PP. 234-246. 1984.

[15] Gikardi, Simon. Writing in Limbo: Modernism and Caribbean Literature. Ithaca: Cornell University Press, 1992.

[16] Gohar, Saddik. Navigating the Post-Colonial: A Study of Contemporary Poetics. Cairo: Eyes Press, 2000.

[17] Gugelburger, George. "Decolonization of the Canon: Consideration of Third World Literature". New Literary History22 (1991): 505-524.

[18] Khouri, M and H. Algar, tr\& ed. An Anthology of Modern Arabic Poetry. Berkeley: University of California Press 1974.

[19] Lodge, David, ed. Twentieth Century Criticism. London: Longman, 1972.

[20] Olson, Gary and Lynn Worsham. "Staging the Politics of Difference: HomiBhabha's Critical Literacy", in Race, Rhetoric and the Postcolonial, ed. Gary Olson and Lynn Worsham. Albany: State University of New York Press. pp. 3-39. 1999.

[21] Slemon, Stephen. "Modernism's Last Post.” Ariel20 (1989): 3-17.

[22] Williams Patrick and Laura Chrisman, ed. Colonial Discourse and PostcolonialTheory: A Reader. London: Harvester Wheatsheaf, 1993.

Citation: Saddik Gohar, "Contextualizing Colonial Strategies in Modernist Arabic Poetics: Rethinking Colonial Politics in Post WWII Arabic Poetry" International Journal On Studies In English Language And Literature (IJSELL), vol 5, no. 11, 2017, pp. 38-47. doi:http://dx.doi.org/10.20431/2347-3134.0511005.

Copyright: (C) 2017 Authors. This is an open-access article distributed under the terms of the Creative Commons Attribution License, which permits unrestricted use, distribution, and reproduction in any medium, provided the original author and source are credited. 